\title{
Soil Enzyme Activities, Microbial Diversity and Available Nutrients Status of an Alfisol under Long Term Fertilization
}

\author{
R.C. Gowda, P. Veeranagappa*, D.C. Hanumanthappa and Muneshwar Singh \\ All India Coordinated Research Project on Long Term Fertilizer Experiments \\ University of Agricultural Sciences, Bengaluru, Karnataka, India \\ *Corresponding author
}

\begin{abstract}
A B S T R A C T
The changes in enzyme activities, microbial diversity and nutrients availability in soil under long term fertilization (30 years) with inorganic fertilizers alone or in combination with organics/amendments were investigated in the present study. The experiment consisted of eleven treatments with four replications with the finger millet-maize cropping sequence. Significantly higher biomass C $(276.53 \mu \mathrm{g} / \mathrm{g})$ and biomass $\mathrm{N}(27.20 \mu \mathrm{g} / \mathrm{g})$ contents were recorded with $100 \% \mathrm{NPK}+\mathrm{FYM}+$ lime and $100 \% \mathrm{NPK}+\mathrm{FYM}$ application respectively. Soil enzyme activities (Acid Phosphotase and Dehydrogenase) were higher in these treatments. The general soil microflora was also higher on application of NPK, FYM and lime. The results also envisaged that application of inorganics alone resulted in decreased nutrients status (available NPK) over balanced fertilizer application. Soil acidification was accelerated with application of nitrogenous fertilizers alone (-1.87 unit reduction in soil $\mathrm{pH}$ over initial) and the soil $\mathrm{pH}$ was maintained in balanced fertilization (6.46). Available nutrients in soil were higher in $100 \% \mathrm{NPK}+\mathrm{FYM}+\mathrm{lime}$ and $100 \%$ NPK+FYM application where the combined application of fertilizers, manure and amendments were undertaken.
\end{abstract}

\section{Introduction}

Studies of microbial biomass $\mathrm{C}, \mathrm{N}$ and enzyme activities provide information on the biochemical processes occurring in the soil and there is growing evidence that soil biological parameters may have a potential as early and sensitive indicators of soil ecological stress and restoration (Dick and Tabatabai, 1992). Soil microbial diversity is one of the most important microbial parameters in soil. It has been demonstrated that soil microbial diversity is affected by anthropogenic disturbance (Fox and MacDonald, 2003). Long-term experiments point to a complex of direct and indirect changes in physicochemical and biological soil properties affected by the application of organic and mineral fertilizers or no fertilizers at all. Fertilization affects soil properties essential for its agricultural quality and ecological balance: the content and transformations of organic carbon (Kubat et al., 2006), acidification and soil reaction (Debreczeni and Kismanyoky, 2005) nutrients contents as well as their availability to plants (Madaras and Lipavsky, 2009).

Microbial community plays a vital role in regulating processes such as decomposition of 
organic matter and nutrient cycling in soil at the ecosystem level (Zeller et al., 2001). The importance of the size of microbial biomass is emphasised by the fact that this is the eye of the needle through which all organic material that enters the soil must pass. Besides the size of microbial biomass, its functional and structural diversity has relevance as well. Functional diversity (e.g., microbial activity) is significant, because $80-90 \%$ of the processes in soil are reactions mediated by microorganisms (Nannipieri and Badalucco, 2003 and Livia Bohme et al., 2005). Among agricultural practices, ploughing, manuring and fertilization and crop rotation have beneficial, harmful or neutral effects on the trinity formed by plants, soil organisms (microbes and fauna) and soil (Bowen and Rovira, 1991 and Mandal et al., 2007).

Application of either alone or dual fertilizers resulted in soil nutrients imbalance, soil acididy and poor crop performance. These changes, in the long-term, are believed to have significant influences on the quality and productive capacity of the soil (Acton and Gregorich, 1995). Effects of management practices on soil quality and productivity are best evaluated using long-term experiments. A long term fertilizer experiment at Bangalore, India was started in 1986-87 with finger millet - maize cropping sequence on a typic kandicustalfs. The objective of the study was to study the soil enzyme activities, microbial diversity and available nutrients status in soil under long term fertilization.

\section{Materials and Methods}

\section{Experimental details}

The experimental site is gio-positioned at an altitude of 930 meters above MSL, latitude of $13^{\circ}$ north, longitude of $77^{\prime \prime} 3^{\prime}$ east. The annual rainfall occurs from April to November with an average rain fall of $920.4 \mathrm{~mm}$. There are eleven fixed treatments established in permanently laid out plots in randomized block design with four replications on finger millet - maize cropping sequence. Neither the treatments nor the management practices in respect of fertilizers doses, irrigation and plant protection measures have changed over the years. The treatments details are as under.

$$
\begin{aligned}
& \mathrm{T}_{1}: 50 \% \mathrm{NPK} \\
& \mathrm{T}_{2}: 100 \% \mathrm{NPK} \\
& \mathrm{T}_{3}: 150 \% \mathrm{NPK} \\
& \mathrm{T}_{4}: 100 \% \mathrm{NPK}+\mathrm{HW} \\
& \mathrm{T}_{5}: 100 \% \mathrm{NPK}+\mathrm{Lime} \\
& \mathrm{T}_{6}: 100 \% \mathrm{NP} \\
& \mathrm{T}_{7}: 100 \% \mathrm{~N} \\
& \mathrm{~T}_{8}: 100 \% \mathrm{NPK}+\mathrm{FYM} \\
& \mathrm{T}_{9}: 100 \% \mathrm{NPK}(\mathrm{S}-\text { free }) \\
& \mathrm{T}_{10}: 100 \% \mathrm{NPK}+\mathrm{FYM}+\text { lime } \\
& \mathrm{T}_{11}: \text { Control }
\end{aligned}
$$

Lime, as per lime requirement test is applied only when found necessary, during the kharif season. Well decomposed Farmyard manure (FYM) at the rate of $15 \mathrm{t} \mathrm{ha}^{-1}$ on dry weight basis is incorporated into the soil 10-15 days before sowing of the kharif crop. Half the dose of the nitrogen, full dose of $\mathrm{P}$ and $\mathrm{K}$ applied as basal and remaining half of nitrogen dose is applied after 25 to 30 days of sowing / transplanting of crops as top dress. Diammonium phosphate (DAP) is used as a source of $\mathrm{P}$ and $\mathrm{N}$ along with urea and muriate of potash (MoP) in $100 \%$ NPK $(-S)$. For all the treatments (except $100 \%$ NPK -S), urea, single super phosphate are used assources of NPK fertilizers. Neither any chemical fertilizer nor any organic manure is used in absolute Control (No NPK) treatment.

\section{Microbial biomass carbon and nitrogen}

Microbial biomass was estimated using the $\mathrm{CHCl}_{3}$ fumigation-extraction method (Vance et al., 1987). Samples of moist soil (10 g) were used, and $\mathrm{K}_{2} \mathrm{SO}_{4}$-extractable $\mathrm{C}$ was 
determined using dichromate digestion. Microbial biomass $\mathrm{N}$ was calculated as a difference in $\mathrm{N}$ content in fumigated and nonfumigated sample $\left(\mathrm{E}_{\mathrm{N}}\right)$ using $\mathrm{k}_{\mathrm{EN}}$ coefficient (microbial biomass $\mathrm{N}=\mathrm{E}_{\mathrm{N}}: \mathrm{k}_{\mathrm{EN}}$ ). The value of $\mathrm{k}_{\mathrm{EN}}=0.54$ was used to calculate microbial biomass N (Jenkinson, 1988).

\section{Dehydrogenase activity}

Soil samples $(3 \mathrm{~g})$ were mixed with $0.04 \mathrm{~g}$ $\mathrm{CaCO}_{3}, 1 \mathrm{ml}$ of $3 \%$ aqueous triphenyltetrazolium chloride (TTC) solution and 2.5 $\mathrm{ml}$ of distilled water in test tubes. The tubes were sealed, shaken and incubated at $37^{\circ} \mathrm{C}$ for $24 \mathrm{hr}$. TTC-formazan was extracted from the soil suspension with $\mathrm{CH}_{3} \mathrm{OH}$, filtered, and made up to $50 \mathrm{ml}$ with additional $\mathrm{CH}_{3} \mathrm{OH}$. The absorbance at $485 \mathrm{~nm}$ of the extracts was measured by spectrophotometer (Shimadzu UV-1800) using $\mathrm{CH}_{3} \mathrm{OH}$ as a blank by following the method as outlined by Casida $e t$ al., (1964).

\section{Acid phosphatase activity}

Acid phosphatase activity was assayed using $1 \mathrm{~g}$ of soil (wet equivalent), $4 \mathrm{ml}$ of $0.1 \mathrm{M}$ modified universal buffer $(\mathrm{pH} 6.5)$, and $1 \mathrm{ml}$ of $25 \mathrm{~m} \mathrm{M}$ p-nitrophenyl phosphate. After incubation for $1 \mathrm{hr}$ at $37 \pm 1^{\circ} \mathrm{C}$, the enzyme reaction was stopped by adding $4 \mathrm{ml}$ of $0.5 \mathrm{M}$ $\mathrm{NaOH}$ and $1 \mathrm{ml}$ of $0.5 \mathrm{M} \mathrm{CaCl}_{2}$ to prevent dispersion of humic substances. After centrifugation at $4000 \mathrm{rpm}$ for $10 \mathrm{~min}$, the absorbance was measured in the supernatant at $400 \mathrm{~nm}$; enzyme activity was expressed as $\mu \mathrm{g} / \mathrm{PNP} / \mathrm{g} / 24 \mathrm{hr}$.

\section{Microbial population}

Ten gram of pooled soil was mixed in $90 \mathrm{ml}$ sterilized blank to give $10^{-1}$ dilution subsequent dilutions to $10^{-6}$ were made by transferring serially $1 \mathrm{ml}$ of the dilution to 9 $\mathrm{ml}$ of sterilized blank. The populations of bacteria, fungi, and actinomycetes were estimated by transferring $1 \mathrm{ml}$ of $10^{-6}$ and $10^{-3}$ and $10^{-4}$ dilutions respectively to a sterile petridish and approximately $20 \mathrm{ml}$ of media viz., soil extract agar for soil bacteria, Martin's rose Bengal agar for fungi and Kuster's agar for actinomycetes respectively was poured into plates the plates were rotated twice in clockwise and anticlockwise direction for uniform distribution of the inoculums. After solidification of media, plates were kept for incubation in an inverted position at $30^{\circ} \mathrm{C}$ for a week time and emerged colonies were counted (Tate, 1995).

\section{Soil analysis}

Soil samples were collected from 0 - to $15-\mathrm{cm}$ soil depth after the harvest of maize during 2015 the samples was air dried, ground and passed through 2-mm sieve for further analysis. The $\mathrm{pH}$ of the soil was determined in 1:2.5 soil: water suspension using $\mathrm{pH}$ meter (Jackson, 1967). The electrical conductivity of the soil samples was measured in the supernatant liquid of 1:2.5 suspension using a conductivity bridge (Jackson, 1973). Soil organic $\mathrm{C}$ concentration was estimated from soil samples through wet oxidation method (Walkley and Black, 1934). The available N (alkaline permanganate method, Subbiah and Asija, 1956); Available P was extracted with $\mathrm{NH}_{4} \mathrm{~F}-\mathrm{HCl}$ solution (Bray and Kurtz, 1945), available potassium was extracted from $1 \underline{\mathrm{N}}$ $\mathrm{NH}_{4} \mathrm{OAC}-\mathrm{K}$ (Hanway and Heidel, 1952). The soil is typic kandicustalfs with sandy clay loam texture. Initially the soil reaction was acidic (6.17), low in organic carbon content $(0.46 \%)$ and available NPK contents of the soil are $256.7 \mathrm{~kg} \mathrm{ha}^{-1}, 34.30 \mathrm{~kg} \mathrm{ha}^{-1}$ and $123.10 \mathrm{~kg} \mathrm{ha}^{-1}$ respectively.

\section{Statistical analysis}

In order to compare the treatments, the data was pooled over the years and an analysis of 
variance (ANOVA) was performed following standard procedures for randomized block design (Gomez and Gomez, 1984). The F-test was used to test significant differences between treatment means. The significant differences between treatments were compared with the critical difference (C.D.) at $5 \%$ level of probability.

\section{Results and Discussion}

\section{Enzyme activities and microbial diversity}

Significantly higher biomass $\mathrm{C}$ was recorded on application of $100 \% \mathrm{NPK}+\mathrm{FYM}+$ lime $(276.53 \mu \mathrm{g} / \mathrm{g}) \quad$ compared to all other treatments. Among the treatments there was no significant difference with respect to microbial biomass $\mathrm{N}$ (Table 1). Phosphatase activity was significantly higher in $100 \%$ NPK+FYM+lime $\quad(118.77 \quad \mu \mathrm{g} / \mathrm{PNP} / \mathrm{g} / 24 \mathrm{hr})$ compared to all other treatments. Dehydrogenase activity recorded a significantly higher activity in $100 \%$ $\mathrm{NPK}+\mathrm{FYM}(65.80 \mu \mathrm{g} / \mathrm{TPF} / \mathrm{g} / 24 \mathrm{hr})$ over all the other treatments. It was noticed that the treatments with combined application of FYM and chemical fertilizers recorded higher biomass and greater enzyme activities compared the inorganic fertilizers alone. The greater activities of phosphatase, in the FYM treated soils may be due to enhanced microbial activity and diversity of phosphate solubilizing bacteria due to manure input over the years. The dehydrogenase activity in this study could not be related to soil organic $\mathrm{C}$ or to microbial biomass $\mathrm{C}$. Dehydrogenase activity, as a measure of soil microbial activity, is strongly influenced by the presence of nitrate, which serves as an alternative electron acceptor resulting in low activities (Sneh Goyal et al., 1999). Dehydrogenase was highly sensitive to the inhibitory effects associated with large fertilizer additions. The effects of fertilization on dehydrogenase activity may be direct, related for example to changes in the availability of nutrients or heavy metals present in the fertilizers as contaminants (Simek et al., 1999).

Among the general microflora significantly higher bacterial population (Fig. 1) was observed in $100 \%$ NPK+FYM+lime application (31.33 cfu g dry wt. soil ${ }^{-1}$ ), which was superior over rest of the treatments. The fingal population also deferred significantly wherein application of $100 \quad \%$ NPK+FYM+lime (17.67 cfu g dry wt. soil ${ }^{-1}$ ) and $100 \%$ NPK+FYM (17.67 cfu g dry wt. soil $^{-1}$ ) recorded the higher population of fungi. Actinomycetes population was significantly higher in $100 \% \mathrm{NPK}+\mathrm{FYM}+$ lime application (7 cfu g dry wt. soil ${ }^{-1}$ ), $100 \%$ NPK+FYM (7 cfu g dry wt. soil ${ }^{-1}$ ) and $150 \%$ NPK (7 cfu g dry wt. soil ${ }^{-1}$ ) which were significantly superior over all the other treatments. Lower population of bacterial, fungal and actinomycetes (15.33, 5.33 and $2 \mathrm{cfu}$ g dry wt. soil ${ }^{-1}$ ) were recorded in absolute control. Use of FYM alone or in combination with chemical fertilizers led to higher numbers of microbes and enhanced microbial respiration than use of chemical fertilizers alone. Farm manure is rich in organic matter and an important source of nutrients for plants and microorganism in soil, its incorporation into soil promotes microbiological activities and improves chemical fertilizer use efficiency. Bacteria were more numerous $\left(1 \times 10^{5} \mathrm{cfu}\right.$ (colonies forming units) g dry wt. soil ${ }^{-1}$ ) than fungi $\left(1 \times 10^{3} \mathrm{cfu}\right.$ g. dry wt. soil $\left.{ }^{-1}\right)$ which may lead to more soil organic matter (SOM) mineralization and less SOM retention in this cropping system (Fig. 1). It is evident from the study that in treatments receiving farm yard manure microbial population were higher compared to the no FYM applied plots and this may be attributed to more availability of carbon (Belay et al., 2002). The results indicates that due to acidification as accelerated by the chemical fertilizers 
(especially urea), the soil reaction was reduced (Fig. 2) when compared to the initial $\mathrm{pH}(6.17)$ except in $100 \% \mathrm{NPK}+\mathrm{FYM}+$ lime (6.46) and control (6.40). The magnitude of reduction was slightly higher where only $\mathrm{N}$ was applied (4.30) followed by $100 \% \mathrm{NP}$ (4.73) this was mainly due to soil acidification caused by the synthetic nitrogen fertilizer.

Table.1 Effect of long term fertilization and cropping on enzyme activities

\begin{tabular}{|c|c|c|c|c|}
\hline Treatments & $\begin{array}{c}\text { Microbial } \\
\text { Biomass C } \\
\mu \mathrm{g} / \mathrm{g}\end{array}$ & $\begin{array}{c}\text { Microbial } \\
\text { Biomass N } \\
\mu \mathrm{g} / \mathrm{g}\end{array}$ & $\begin{array}{c}\text { Acid } \\
\text { Phosphotase } \\
\mu \mathrm{g} / \mathrm{PNP} / \mathrm{g} / 24 \mathrm{hr}\end{array}$ & $\begin{array}{l}\text { Dehydrogenase } \\
\mu \mathrm{g} / \mathrm{TPF} / \mathrm{g} / 24 \mathrm{hr}\end{array}$ \\
\hline $\mathrm{T}_{1}: 50 \% \mathrm{NPK}$ & 229.36 & 24.0 & 88.36 & 56.20 \\
\hline $\mathrm{T}_{2}: 100 \% \mathrm{NPK}$ & 241.06 & 25.1 & 92.43 & 62.00 \\
\hline $\mathrm{T}_{3}: 150 \% \mathrm{NPK}$ & 264.20 & 26.7 & 94.59 & 64.40 \\
\hline $\mathrm{T}_{4}: 100 \% \mathrm{NPK}+\mathrm{HW}$ & 238.46 & 26.8 & 88.56 & 52.00 \\
\hline $\mathrm{T}_{5}: 100 \% \mathrm{NPK}+$ Lime & 236.40 & 25.0 & 87.79 & 59.80 \\
\hline $\mathrm{T}_{6}: 100 \% \mathrm{NP}$ & 204.96 & 23.6 & 88.11 & 42.20 \\
\hline $\mathrm{T}_{7}: 100 \% \mathrm{~N}$ & 206.97 & 23.9 & 85.21 & 43.60 \\
\hline $\mathrm{T}_{8}: 100 \% \mathrm{NPK}+\mathrm{FYM}$ & 262.50 & 27.2 & 102.37 & 65.80 \\
\hline $\mathrm{T}_{9}: 100 \% \mathrm{NPK}(\mathrm{S}$-free $)$ & 237.06 & 24.6 & 88.57 & 33.80 \\
\hline $\mathrm{T}_{10}: 100 \% \mathrm{NPK}+\mathrm{FYM}+$ Lime & 276.53 & 26.1 & 118.77 & 60.20 \\
\hline $\mathrm{T}_{11}:$ Control & 216.36 & 23.4 & 81.73 & 47.00 \\
\hline CD@ $9 \%$ & 9.02 & 4.25 & 12.99 & 4.65 \\
\hline
\end{tabular}

Table.2 Available nutrients status in soil after 28th cycle of finger millet- maize cropping sequence

\begin{tabular}{|c|c|c|c|c|c|c|}
\hline \multirow{2}{*}{ Treatments } & Avail.N & Avail. $\mathrm{P}_{2} \mathrm{O}_{5}$ & Avail. $\mathrm{K}_{2} \mathrm{O}$ & Exch.Ca & Exch.Mg & \multirow{2}{*}{$\begin{array}{l}\text { Avail.S } \\
\text { (kg/ha) }\end{array}$} \\
\hline & \multicolumn{3}{|c|}{ (kg/ha) } & \multicolumn{2}{|c|}{$\left(\mathbf{c ~ m o l ~ p ^ { + } / k g )}\right.$} & \\
\hline $50 \% \mathrm{NPK}$ & 179.69 & 61.02 & 142.11 & 5.18 & 3.03 & 28.72 \\
\hline $100 \%$ NPK & 206.65 & 83.06 & 170.35 & 4.25 & 2.50 & 28.24 \\
\hline $150 \% \mathrm{NPK}$ & 262.80 & 109.15 & 229.16 & 4.43 & 2.93 & 28.13 \\
\hline $100 \% \mathrm{NPK}+\mathrm{HW}$ & 215.20 & 79.54 & 180.84 & 5.00 & 2.65 & 27.21 \\
\hline $100 \%$ NPK+Lime & 226.27 & 82.23 & 185.48 & 5.85 & 2.90 & 29.28 \\
\hline $100 \% \mathrm{NP}$ & 214.18 & 79.07 & 80.00 & 4.08 & 2.68 & 28.54 \\
\hline $100 \% \mathrm{~N}$ & 223.29 & 42.48 & 72.84 & 3.85 & 2.20 & 28.54 \\
\hline $100 \% \mathrm{NPK}+\mathrm{FYM}$ & 284.35 & 88.81 & 200.57 & 4.75 & 3.08 & 29.33 \\
\hline $100 \%$ NPK(S-free $)$ & 217.20 & 85.33 & 179.42 & 4.43 & 2.55 & 28.89 \\
\hline $\begin{array}{l}100 \% \mathrm{NPK}+\mathrm{FYM}+\mathrm{li} \\
\text { me }\end{array}$ & 289.37 & 94.54 & 213.45 & 6.50 & 3.50 & 29.81 \\
\hline Control & 172.01 & 38.89 & 88.54 & 5.00 & 3.00 & 29.57 \\
\hline SEm \pm & 5.57 & 2.90 & 7.37 & 0.26 & 0.20 & 0.74 \\
\hline CD @5\% & 16.44 & 8.55 & 21.73 & 0.77 & 0.60 & 2.19 \\
\hline Initial & 257.0 & 34.3 & 123.1 & 3.25 & 1.55 & 9.06 \\
\hline
\end{tabular}


Fig.1 Effect of long term fertilization and cropping on microbial diversity

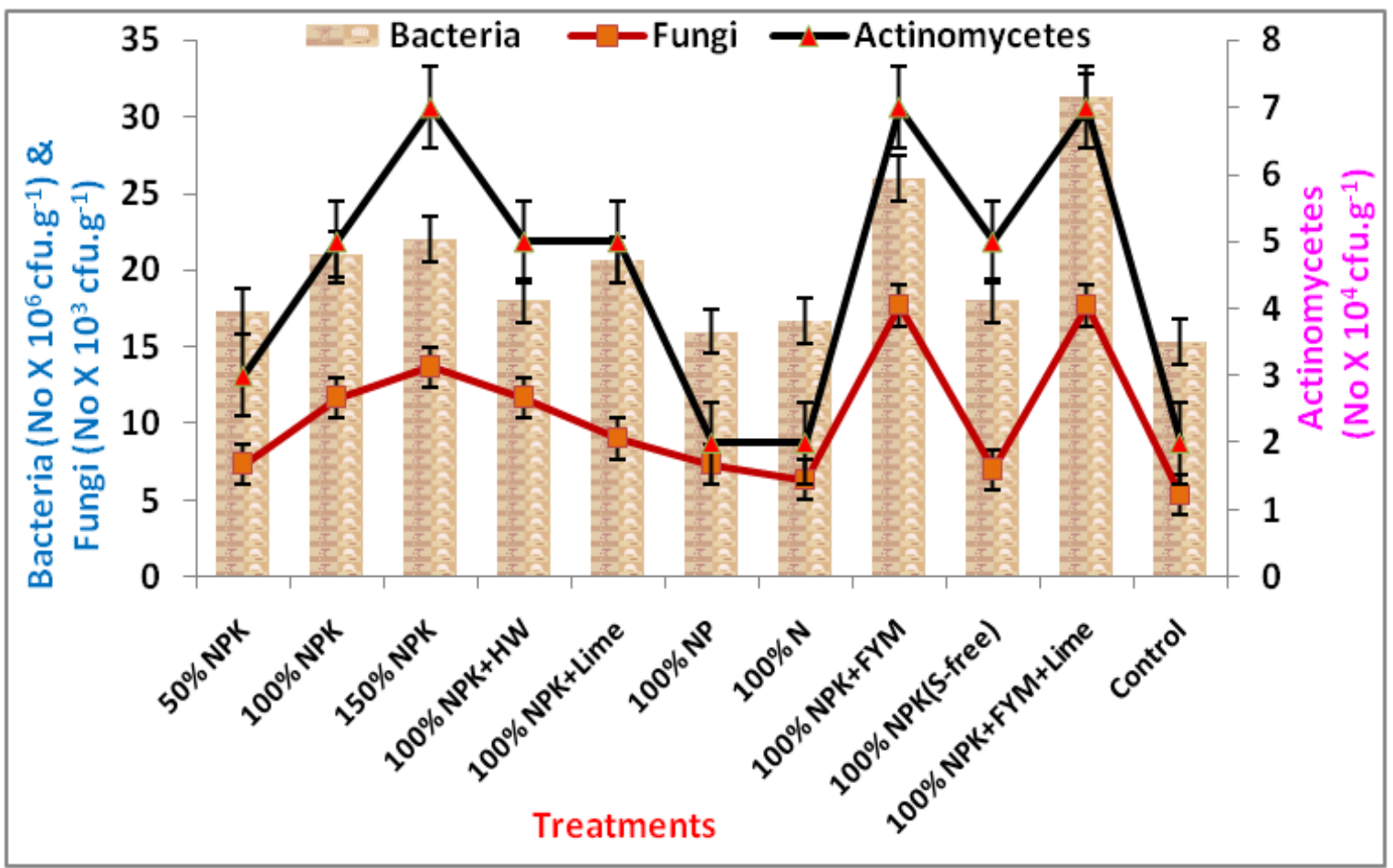

Fig.2 Effect of long term fertilization on soil $\mathrm{pH}$, electrical conductivity and organic carbon content

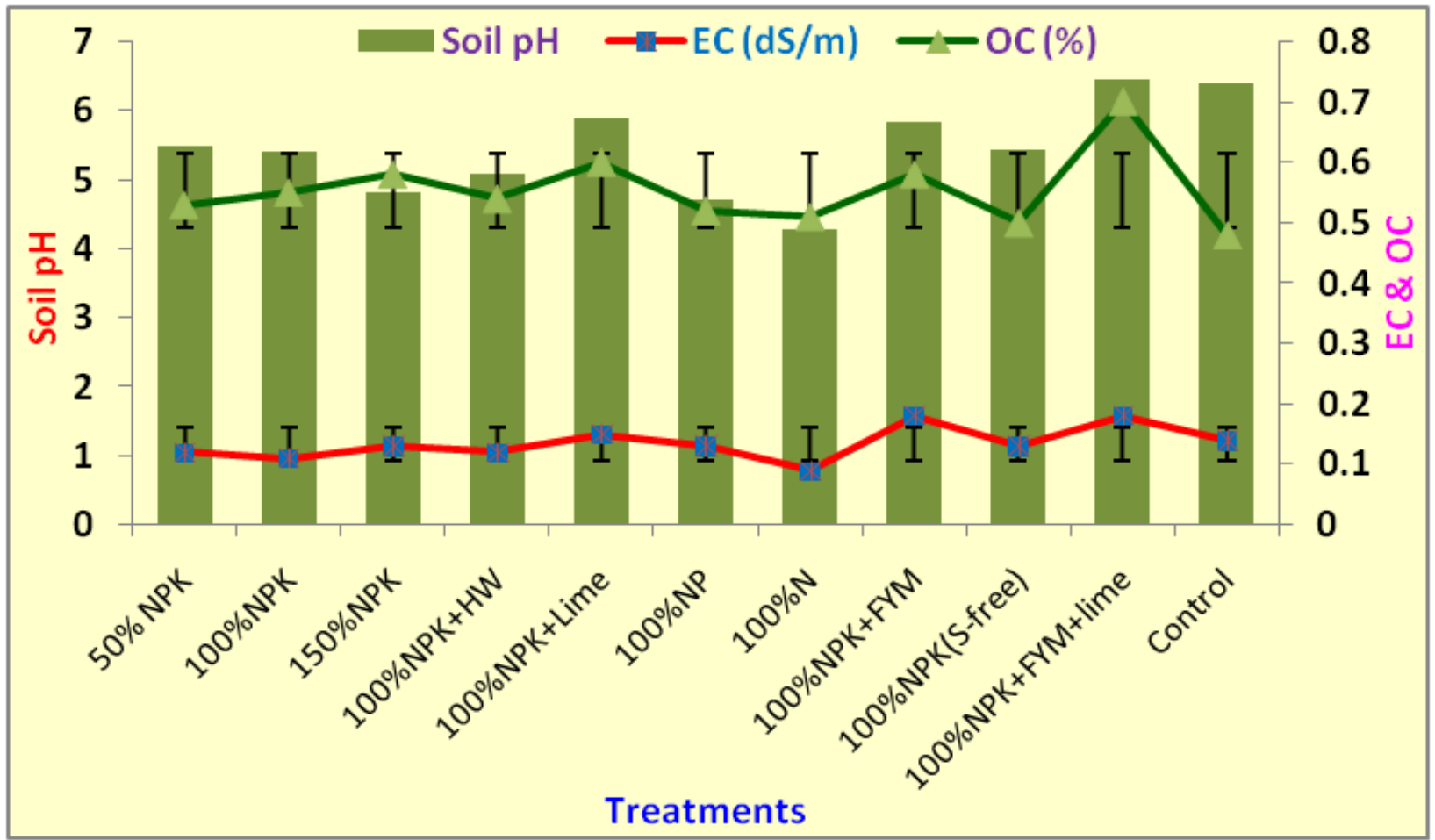


The organic carbon content in all the treatments was slightly increased over its initial status $(0.46 \%)$ due to $\mathrm{C}$ addition through the roots and crop residues, higher humification rate constant, and lower decay rate (Kundu et al., 2002 and Enke Liu et al., 2010). Significantly higher organic carbon content was recorded in $100 \%$ $\mathrm{NPK}+\mathrm{FYM}+$ lime (0.70) followed by $100 \%$ NPK+lime $(0.60 \%)$. Higher soil organic carbon content was noted on combined application of FYM and mineral fertilizers (Bhattacharyya et al., 2010). Lower OC contents were observed in control $(0.48 \%)$ and in $100 \% \mathrm{~N}$ alone $(0.50 \%)$.

Among the major nutrients status in soil, available nitrogen content of soil has decreased in all the treatments except in 100 $\% \mathrm{NPK}+\mathrm{FYM}+$ lime $100 \% \mathrm{NPK}+\mathrm{FYM}$ and $150 \% \mathrm{NPK}$, the magnitude of nitrogen loss was higher in absolute control where there was no application of fertilizers (Table 2). This indicated that the loss of nitrogen is higher over its application due to crop removal and other losses. Application of $100 \%$ NPK + FYM and super optimal dose (150\% NPK) recorded a significant build-up of available $\mathrm{P}$ followed by all other treatments. The long-term continuous inorganic fertilizer application, had a significant contribution to soil $\mathrm{P}$ availability and its build up in soil due to soil fixation (Wang et al., 2010). Maximum potassium buildup was recorded on application of $150 \%$ NPK (106.06 kg ha ${ }^{-1}$ ) followed by $100 \%$ $\mathrm{NPK}+\mathrm{FYM}+$ lime and other treatments, the available potassium content in soil was depleted in treatments where $\mathrm{K}$ was not applied $\left(\mathrm{T}_{6}, \mathrm{~T}_{7}\right.$ and $\left.\mathrm{T}_{11}\right)$. The depletion of major nutrients status in soil was due to higher crop removal, imbalanced nutrition or no application of fertilizers. Regular application of lime and FYM resulted in build of phosphorus and potassium. The present results corroborated the findings of Jaskulska et al., (2014). The secondary nutrients statues in soil found to increase in all the treatments over the initial values, however application of balanced fertilizers resulted in higher buildup in soil compared to absolute control and inorganics alone. The increase in these nutrients contents is due to application of chemical fertilizers, farm yard manure and lime which contained appreciable amounts of these elements.

In conclusion, balanced nutrition (100\% $\mathrm{NPK}+\mathrm{FYM}+$ lime) ensured greater microbial activities and higher microbial population suggesting their vital role as a part of sustainable agriculture. Application of balanced fertilizers along with organic manure and amendments could result in maintaining and sustaining the soil fertility and productivity over the years. Application of chemical fertilizers alone resulted in soil acidification up to 1.87 unit reduction over the original value wherein application of 100 $\% \mathrm{NPK}+\mathrm{FYM}+$ lime maintained the soil $\mathrm{pH}$ (6.46) compared to all the other treatments. Application of farm manure at $10 \mathrm{t} \mathrm{ha}^{-1}$ along with recommended dose of fertilizers and lime found promising in term of sustaining crop and soil productivity. There was buildup of phosphorus and potassium in soil over the initial status.

\section{References}

Acton, D.F. and Gregorich, L.J. 1995. The Health of Our Soils: Toward Sustainable Agriculture in Canada. Agric. Agri-Food Canada, CDR Unit, Ottawa.

Belay, A., Claassens, A.S. and Wehner, F.C. 2002. Effect of direct nitrogen and potassium and residual phosphorus fertilizers on soil chemical properties, microbial components and maize yield under long-term crop rotation. Biol. Fertil. Soils, 35: 420-42. 
Bhattacharyya, R., Prakash, V., Kundu, S., Srivastva, A.K., Gupta, H.S. and Mitra, S. 2010. Long term effects of fertilization on carbon and nitrogen sequestration and aggregate associated carbon and nitrogen in the Indian subHimalayas. Nutr. Cycl. Agroecosyst., 86: $1-16$.

Bowen, G.D. and Rovira, A.D. 1991. The rhizosphere - the hidden half of the hidden half. In: Waisel, Y., Eshel, A., KafkaW, U. (Eds.), Plant Roots - The Hidden Half. Marcel Dekker, New York, pp. 641-669.

Bray, R.H. and Kurtz, L.T. 1945. Determination of total, organic, and available forms of phosphorus in soils. Soil Sci., 59: 39-45.

Casida, L.E.JR., Klein, D.A. and Santaro, T. 1964. Soil dehydrogenase activity. Soil Sci., 96: 371-376.

Debreczeni, K. and Kismányoky, T. 2005. Acidification of soils in long-term field experiments. Commun. Soil Sci. Pl. Anal., 36: 321-329.

Dick, W.A. and Tabatabai, M.A. 1992. Potential uses of soil enzymes. In: Metting, B. (Ed.). Soil Microbial Ecology, Marcel Dekker, New York, pp. 95-127.

Enke Liu, Changrong Yan, Xurong Mei, Wenqing He, So Hwat Bing, Linping Ding, Qin Liu, Shuang Liu and Tinglu Fan. 2010. Long-term effect of chemical fertilizer, straw, and manure on soil chemical and biological properties in northwest China. Geoderma, 158(3-4): 173-180.

Fox, C.A. and Macdonald, K.B. 2003. Challenges related to soil biodiversity research in agro-ecosystems - issues within the context of scale of observation. Can. J. Soil Sci., 83: 231244.

Gomez, K.A. and Gomez, A.A. 1984. Statistical procedures for agricultural research, IRRI, Willey -Inter Science Pub. Newyork, USA.

Hanway, J.J. and Heidel, H. 1952. Soil analyses methods as used in Iowa State College Soil Testing Laboratory. Iowa Agri., 57: 1-31.

Jackson, M.L. 1967. Soil Chem. Anal., Prentice Hall India Pvt. Ltd., New Delhi.

Jackson, M.L. 1973. Soil chemical Analysis. Prentice Hall India Pvt. Ltd., New Delhi.

Jaskulska, I., Jaskulski, D. and Kobierski, M. 2014. Effect of liming on the change of some agrochemical soil properties in a long-term fertilization experiment. $\mathrm{Pl}$. Soil Environ., 60(4): 146-150.

Jenkinson, D.S. 1988. The determination of microbial biomass carbon and nitrogen in soil. In: Wilson J.R. (Ed.): Advances in Nitrogen Cycling in Agricultural Ecosystems. CAB International, Wallingford: 368-386.

Kubat, J., Cerhanova, D., Novakova, J. and Lipavsky, J. 2006. Total organic carbon and its composition in long-term field experiments in the Czech Republic. Arch. Agron. Soil Sci., 52: 495-505.

Kundu, S., Prakash, V., Ghosh, B.N., Singh, R.D., Srivastva, A.K. 2002. Quantitative relationship between annual carbon inputs and soil organic carbon build-up in soybean (Glycine max)-wheat (Triticum aestivum) cropping sequence. $2^{\text {nd }}$ Intern. Agron. Congress, Nov. 26-30, New Delhi, India, pp. 108-110.

Livia Bohme, Uwe Langer and Frank Bohme, 2005, Microbial biomass, enzyme activities and microbial community structure in two European long-term field experiments. Agri. Ecosystems and Environ., 109: 141-152.

Madaras, M. and Lipavsky, J. 2009. Interannual dynamics of available potassium in a long-term fertilization 
experiment. Pl. Soil Environ., 55: 334343.

Mandal, A., Patra, A.K., Dhyan Singh, Anand Swarup and Ebhin Masto, R. 2007. Effect of long-term application of manure and fertilizer on biological and biochemical activities in soil during crop development stages. Biores. Technol., 98: 3585-3592.

Nannipieri, P. and Badalucco, L. 2003. Biological processes. In: Benbi, D.K., Nieder, R. (Eds.), Handbook of Processes and Modelling in the SoilPlant System. Haworth Press, Binghamton, NY, pp. 57-82.

Simek, M., Hopkins, D.W., Kalcík, J., Picek, T., Santruckova, H., Stana, J. and Travník, K. 1999. Biological and chemical properties of arable soils affected by long-term organic and inorganic fertilizer applications. Biol. Fertil. Soils, 29: 300-308

Sneh Goyal, Chander, K., Mundra, M.C. and Kapoor, K.K. 1999. Influence of inorganic fertilizers and organic amendments on soil organic matter and soil microbial properties under tropical conditions. Biol. Fertil. Soils, 29: 196200

Subbiah, B.V. and Asija, G.L. 1956. A rapid procedure for the estimation of available nitrogen in soils. Curr. Sci., 25: 259-260.

Tate, R.L. 1995. Soil Microbiology. John Wiley and sons, New York.

Walkley, A. J. and Black, C. A. 1934. An examination of the method for determining soil organic matter and a proposed modification of the chromic acid titration method. Soil Sci., 37: 2938.

Wang, J., Liu, W.Z., Mu, H.F. and Dang, T.H. 2010. Inorganic phosphorus fractions and phosphorus availability in a calcareous soil receiving 21-year superphosphate application. Pedosphere, 20(3): 304-310.

Zeller, V., Bardgett, R.D. and Tappeiner, U. 2001. Site and management effects on soil microbial properties of subalpine meadows: A study of land abandonment along a north-south gradient in the European Alps. Soil Biol. Biochem., 33: 639-649.

\section{How to cite this article:}

Gowda, R.C., P. Veeranagappa, D.C. Hanumanthappa and Muneshwar Singh. 2017. Soil Enzyme Activities, Microbial Diversity and Available Nutrients Status of an Alfisol under Long Term Fertilization. Int.J.Curr.Microbiol.App.Sci. 6(5): 1483-1491. doi: https://doi.org/10.20546/ijcmas.2017.605.161 